\title{
Lupin protein isolate and cysteine-supplemented casein reduce calcification of atherosclerotic lesions in apoE-deficient mice
}

\author{
Kristin Weisse, Corinna Brandsch, Frank Hirche, Klaus Eder and Gabriele I. Stangl* \\ Institute of Agricultural and Nutritional Sciences, Martin Luther University Halle-Wittenberg, \\ Von Danckelmann Platz. 2, D-06120 Halle (Saale), Germany
}

(Received 18 March 2009 - Revised 6 July 2009 - Accepted 13 July 2009 - First published online 27 August 2009)

Protein from lupin is supposed to have anti-atherogenic effects due to its lipid-lowering properties in laboratory animals. It is further suggested that the amino acid cysteine plays a crucial role in this aspect. The objective of the present study was to compare the effects of lupin protein and cysteine-supplemented casein with those of casein on atherosclerotic lesion development in apoE-deficient mice. For that purpose, thirty mice were fed an egg albumin-based Western-type diet containing test protein $(100 \mathrm{~g} / \mathrm{kg})$ for 4 months. ApoE-deficient mice fed the lupin protein or the cysteine-supplemented casein had more than $50 \%$ less aortic calcification than mice fed casein $(P<0.05)$. The quantified lesion area as a percentage of the total surface area, as well as the collagen and fat content of the lesions were not different between the three groups of mice. The concentration of VLDL TAG was higher in mice fed the lupin protein and the cysteine-supplemented casein than in mice fed casein $(P<0 \cdot 05)$. The cholesterol concentrations of VLDL, LDL and HDL from mice fed the lupin protein and cysteine-supplemented casein were not different compared with the mice fed casein. Also, the plasma concentrations of homocysteine, Ca, inorganic phosphate, and the activity of glutathione peroxidase in plasma and liver did not differ between the three groups of mice. The present study shows that lupin protein and cysteine-supplemented casein compared with casein reduce the calcification of atherosclerotic lesions in apoE-deficient mice. This effect seems not to be mediated by effects on plasma lipoproteins, homocysteine and circulating minerals.

Lupin protein: Cysteine: Atherosclerotic lesions: ApoE-deficient mice

Varieties of sweet lupin have been cultivated for centuries for domestic animal feed, but also for human nutrition, mainly in several parts of Australia, Europe and South America. Their use in the food industry is being developed, and lupin protein is beginning to replace soyabean protein in several food products $^{(1)}$. It is a well-known fact that soyabean protein compared with casein has a hypolipaemic action in human subjects and animals ${ }^{(2)}$. Recent studies have shown that protein extracts from white lupin (Lupinus albus) are also capable of lowering plasma cholesterol ${ }^{(3,4)}$ and TAG concentrations ${ }^{(5,6)}$ in hypercholesterolaemic laboratory animals. A recent study has further shown that isolated protein from lupin reduces focal plaque development in the common carotid arteries in a rabbit model of atherosclerosis ${ }^{(4)}$. The authors suggest that the anti-atherosclerotic effect of lupin protein is caused by the hypocholesterolaemic effect of the lupin protein which was observed in that study compared with casein.

To further elucidate the anti-atherogenic effects and mechanism(s) of lupin protein, other animal models should also be used to fully reproduce human atherosclerotic lesions. ApoEdeficient mice are currently regarded as one of the most appropriate animal models for human atherosclerosis because they develop severe hypercholesterolaemia and atherosclerotic lesions that are similar in distribution and appearance to those observed in humans ${ }^{(7,8)}$. Thus, the present study aimed to investigate the effects of a protein from blue lupin (L. angustifolius) compared with casein on circulating plasma lipids and the development of atherosclerotic lesions by using apoE-deficient mice as a model. In most rat studies dealing with the effects of plant proteins on lipid metabolism the test protein was added to the diet in large amounts up to $25 \%$ as an exclusive protein source $e^{(9,10)}$. However, such large amounts of lupin protein are unrealistic in practical nutrition and the use of lupin protein as an exclusive protein source involves the risk that essential amino acids do not meet the requirement for growing mice. Therefore, we decided to add the dietary test proteins in amounts of $10 \%$ to an egg albumin-based diet. Casein was used as a reference protein because most of the previous studies which investigated the effects of plant proteins, including lupin protein, on lipid metabolism or atherosclerosis used casein as a control protein $^{(3-5,10,11)}$.

A series of experiments dealing with the effects of dietary proteins on lipid metabolism supports a role of individual amino acids in alteration of lipid levels and subsequently in atherogenesis $^{(12,13)}$, although it is not yet clear which of the amino acids could be responsible for the lipid-lowering action. We assume that cysteine could be one of these

Abbreviations: FAS, fatty acid synthase; GPx, glutathione peroxidase; LPL, lipoprotein lipase.

* Corresponding author: Professor Dr Gabriele I. Stangl, fax +49 345 5527124, email gabriele.stangl@landw.uni-halle.de 
Table 1. Composition of the experimental diets $(\mathrm{g} / \mathrm{kg})$

\begin{tabular}{lccc}
\hline & $\begin{array}{c}\text { Control diet } \\
\text { with casein }\end{array}$ & $\begin{array}{c}\text { Lupin protein } \\
\text { diet }\end{array}$ & $\begin{array}{c}\text { Cysteine-supplemented } \\
\text { casein diet }\end{array}$ \\
\hline Egg albumin & 100 & 100 & 100 \\
Casein & 100 & - & 95 \\
Lupin protein & - & 100 & - \\
L-Cysteine & - & - & 5 \\
Maize starch & 278.5 & 278.5 & 278.5 \\
Sucrose & 200 & 200 & 200 \\
Lard & 210 & 210 & 210 \\
Cellulose & 50 & 50 & 50 \\
Vitamin and mineral mixture & 60 & 60 & 60 \\
Cholesterol & 1.5 & 1.5 & 1.5 \\
\hline
\end{tabular}

amino acids because lipid-lowering proteins such as soyabean $\operatorname{protein}^{(9)}$, fish protein ${ }^{(14)}$ and also lupin protein ${ }^{(5,6)}$ contain higher amounts of cysteine than casein. Balb/cA mice treated with five cysteine-containing agents had significantly lower concentrations of TAG and cholesterol in plasma and liver $^{(15)}$, and mice fed a high-fat diet with cysteine-containing compounds had a lower synthesis of TAG and cholesterol in liver $^{(16)}$ than mice fed a diet without cysteine. Therefore, besides lupin protein, we also tested the effect of a cysteinesupplemented casein diet on the development of atherosclerotic lesions.

In addition to the analysis of plaque development and concentrations of lipids in plasma and lipoproteins, plasma concentrations of homocysteine, $\mathrm{Ca}$, inorganic phosphate and glutathione, the activities of glutathione peroxidase (GPx) in plasma and liver, the concentrations of cholesterol oxidation products in LDL and the expression of hepatic genes involved in lipid metabolism should help to elucidate possible mechanisms by which dietary proteins may influence atherogenesis.

\section{Materials and methods}

\section{Animals and diets}

A total of thirty male apoE-deficient mice (B6.129P2-

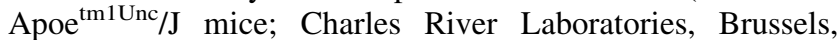
Belgium) with an initial body weight of 24.0 (SD 1.5) $\mathrm{g}$ were randomly assigned to three groups of ten mice each. All mice were kept individually in Macrolon cages in a room maintained at $22(\mathrm{SD} 2){ }^{\circ} \mathrm{C}$ and $50-60 \%$ relative humidity with lighting from 06.00 to 18.00 hours.

The mice were fed a semi-synthetic Western-type diet which contained $210 \mathrm{~g}$ lard $/ \mathrm{kg}, 1.5 \mathrm{~g}$ cholesterol $/ \mathrm{kg}$ and $200 \mathrm{~g}$ protein $/ \mathrm{kg}$ which consisted of $100 \mathrm{~g}$ egg albumin $/ \mathrm{kg}$ in order to meet the amino acid requirements of the mice and $100 \mathrm{~g}$ test protein $/ \mathrm{kg}$. The group fed $100 \mathrm{~g}$ casein $/ \mathrm{kg}$ served as a control. The experimental proteins consisted either of protein from blue lupin or of casein supplemented with cysteine. All diets were freeze-dried to ensure the integrity of the test proteins and to avoid formation of Maillard products. The composition of the semi-synthetic diets is shown in Table 1. Vitamins and minerals were supplemented according to recommendations of the American Institute of Nutrition (AIN)-93M ${ }^{(17)}$. Nipple drinkers allowed free access to water.
The experimental diets were fed for 16 weeks. Body weight and food intake were recorded weekly.

\section{Preparation and characterisation of the dietary proteins}

Casein was obtained from Meggle (Wasserburg, Germany) and was not further processed. The protein isolate of the blue lupin was obtained from the Fraunhofer Institute (IVV, Freising, Germany); it was extracted from de-oiled lupin seeds and separated by procedures as described elsewhere ${ }^{(18)}$. Isoflavone concentrations of the lupin protein were analysed according to an HPLC method ${ }^{(19)}$. The concentrations of genistein, daidzein and genistin of the lupin protein used in the present study were below the detection limits of $2.22 \mu \mathrm{mol} / \mathrm{kg}$ for genistein, $1.18 \mu \mathrm{mol} / \mathrm{kg}$ for daidzein and $1.39 \mu \mathrm{mol} / \mathrm{kg}$ for genistin. The cysteine-supplemented casein was produced by mixing $95 \%$ casein and $5 \%$ cysteine. For analysis of the amino acid concentrations in the diets, samples were oxidised and then hydrolysed with $6 \mathrm{M}-\mathrm{HCl}$. Separation and quantification of the amino acids were performed by ion exchange chromatography following post-column derivatisation in an amino acid analyser (Biotronic LC 3000; EppendorfBiotronic, Hamburg, Germany) ${ }^{(5)}$. The concentrations of amino acids in the experimental diets are shown in Table 2.

Table 2. Amino acid composition of the experimental diets $(\mathrm{g} / \mathrm{kg})$

\begin{tabular}{|c|c|c|c|}
\hline & $\begin{array}{l}\text { Control diet } \\
\text { with casein }\end{array}$ & $\begin{array}{l}\text { Lupin } \\
\text { protein diet }\end{array}$ & $\begin{array}{c}\text { Cysteine-supplemented } \\
\text { casein diet }\end{array}$ \\
\hline Alanine & $8 \cdot 2$ & $8 \cdot 3$ & $8 \cdot 1$ \\
\hline Arginine & 8.4 & $16 \cdot 5$ & $8 \cdot 2$ \\
\hline Aspartic acid & $15 \cdot 8$ & $18 \cdot 7$ & 15.5 \\
\hline Cysteine & $2 \cdot 8$ & $3 \cdot 7$ & $7 \cdot 8$ \\
\hline Glutamic acid & 34.7 & $36 \cdot 2$ & $33 \cdot 6$ \\
\hline Glycine & 4.9 & 6.9 & $4 \cdot 8$ \\
\hline Histidine & $7 \cdot 4$ & $7 \cdot 1$ & $7 \cdot 2$ \\
\hline Isoleucine & $9 \cdot 2$ & $8 \cdot 5$ & $8 \cdot 9$ \\
\hline Leucine & $16 \cdot 7$ & $14 \cdot 8$ & $16 \cdot 3$ \\
\hline Lysine & $13 \cdot 4$ & $9 \cdot 8$ & $13 \cdot 0$ \\
\hline Methionine & $5 \cdot 8$ & 3.6 & $5 \cdot 7$ \\
\hline Phenylalanine & $10 \cdot 2$ & $9 \cdot 2$ & $9 \cdot 9$ \\
\hline Proline & $15 \cdot 7$ & $8 \cdot 0$ & $15 \cdot 1$ \\
\hline Serine & $10 \cdot 7$ & $10 \cdot 2$ & $10 \cdot 5$ \\
\hline Threonine & $7 \cdot 9$ & $7 \cdot 0$ & $7 \cdot 7$ \\
\hline Tryptophan & $8 \cdot 4$ & $16 \cdot 5$ & $8 \cdot 2$ \\
\hline Tyrosine & $7 \cdot 7$ & $6 \cdot 2$ & 7.5 \\
\hline Valine & $11 \cdot 8$ & $9 \cdot 1$ & 11.5 \\
\hline
\end{tabular}




\section{Sample collection}

At the end of the experimental period of 16 weeks, mice were killed. Whole blood was collected into EDTA in polyethylene tubes and plasma was separated by centrifugation at $1500 \mathrm{~g}$ for $10 \mathrm{~min}$ at $4^{\circ} \mathrm{C}$. Plasma samples were stored at $-20^{\circ} \mathrm{C}$. Livers were excised, weighed and immediately snap-frozen in liquid $\mathrm{N}_{2}$ and stored at $-80^{\circ} \mathrm{C}$.

\section{Analysis of plasma and liver lipids}

Plasma VLDL, LDL and HDL were separated by step-wise ultracentrifugation $\left(900000 \mathrm{~g}\right.$ at $4^{\circ} \mathrm{C}$ for $1.5 \mathrm{~h}$; Mikro-Ultrazentrifuge, Sorvall Products, Bad Homburg, Germany) by appropriate density cuts (VLDL, $0.95<\rho<1.006 \mathrm{~kg} / \mathrm{l}$; LDL,$\quad 1.006 \mathrm{~kg} / \mathrm{l}<\rho<1.063 \mathrm{~kg} / \mathrm{l} ; \quad$ HDL,$\quad \rho>1.063 \mathrm{~kg} / \mathrm{l})$. Plasma densities were adjusted by sodium chloride and potassium bromide. Lipids from liver were extracted with a mixture of $n$-hexane and isopropanol $(3: 2, \mathrm{v} / \mathrm{v})$ and the concentrations of lipids in liver were determined after drying a sample of the lipid extracts and dissolving the lipids with Triton- $\mathrm{X}^{(5)}$. Concentrations of cholesterol and TAG in plasma lipoproteins and liver were examined using enzymic reagent kits (catalogue no. 1.13009990314 and catalogue no. 1.57609990 314; DiaSys Diagnostic Systems, Holzheim, Germany).

\section{Tissue preparation and morphometric determination of atherosclerosis}

The aortic preparation and histological methods were performed according to Teupser et al. ${ }^{(20)}$ and Mueller et al. ${ }^{(21)}$. For preparation of the aortic root sections, the vasculature was perfused with $0.9 \% \mathrm{NaCl}$, and the ventricular edge and approximately $1 \mathrm{~mm}$ of the aortic root were immediately dissected under a stereomicroscope and cryomounted in mounting medium (tissue freezing medium ${ }^{\circledR}$, Jung; Leica Instruments, Nussloch, Germany). To quantify atherosclerosis at the aortic root, serial $10 \mu \mathrm{m}$ thick slices (CM1800 microtome, Jung; Leica) were collected, beginning at the aortic valve area (point 0 ). Four sections each were stained with haematoxylin-eosin (sections from 0 to $40 \mu \mathrm{m}$ ), Goldner's trichrome for collagen structures (sections from 80 to $120 \mu \mathrm{m}$ ), von Kossa for vascular calcification (sections from 160 to $200 \mu \mathrm{m}$ ) and Oil red $\mathrm{O}$ for vascular lipids (sections from 240 to $280 \mu \mathrm{m})$. Histomorphological characterisation and computerised morphometric quantification (Zeiss-Axiolab microscope (Carl Zeiss, Jena, Germany); TK-1070E colour video camera (JVC, Yokohama, Japan); LuciaG 3.2 software (Laboratory Imaging, Prague, Czech Republic)) of the atherosclerotic lesions were performed, blinded to the protocol. The cross-section surface area of the total vessel, the cross-section surface area of the lesion, the calcification area, the collagen area and the lipid area were assessed. The relative lesion area (expressed relative to the total surface area), the relative collagen area (expressed relative to the lesion area), the relative lipid area (expressed relative to the total surface area) and the relative calcification area (expressed relative to the total surface area) were used to show individual atherosclerosis development in the aortic root.
Analysis of plasma and liver concentrations of cysteine, homocysteine and total glutathione in plasma and liver

For measurement of hepatic total homocysteine (free homocysteine, homocysteine disulfides and homocysteine-cysteine mixed disulfides), cysteine and total glutathione (reduced and oxidised form) concentrations, samples of liver were thawed and homogenised in ice-cold PBS. Concentrations of plasma and liver cysteine, homocysteine and total glutathione were determined by HPLC ${ }^{(22)}$. The homogenates of liver and the plasma samples were applied to an HPLC column (LiChrospher $100 \mathrm{RP}-18 \mathrm{e}, 250 \times 4 \mathrm{~mm}^{2}, 5 \mu \mathrm{m}, 30^{\circ} \mathrm{C}$; Hewlett-Packard, Waldbronn, Germany). The mobile phase was a $0 \cdot 1 \mathrm{M}$-acetate buffer containing $2 \%(\mathrm{v} / \mathrm{v})$ methanol $(\mathrm{pH} 4.0)$ and a $0.1 \mathrm{M}-$ phosphate buffer containing $3 \%(\mathrm{v} / \mathrm{v})$ methanol $(\mathrm{pH} 6 \cdot 0)$. Samples $(10 \mu \mathrm{l})$ were injected, the flow rate was $1.1 \mathrm{ml} / \mathrm{min}$, and the elution was monitored at an excitation wavelength of $385 \mathrm{~nm}$ and an emission wavelength of $515 \mathrm{~nm}$.

\section{Analysis of glutathione peroxidase activity in plasma and liver}

GPx activity in plasma and liver was determined indirectly by a method of Levander et al. ${ }^{(23)}$. In brief, the GPx activity was determined at $37^{\circ} \mathrm{C}$ by recording the decrease in absorbance at $340 \mathrm{~nm}$ following the oxidation of NADPH in the presence of butyl hydroperoxide (Fluka, Buchs, Switzerland), reduced glutathione (Sigma, Deisenhofen, Germany) and yeast glutathione reductase (Fluka). For measurement of hepatic GPx activity, liver samples were homogenised in five volumes $(\mathrm{w} / \mathrm{v})$ of $10 \mathrm{~mm}$-phosphate buffer $(\mathrm{pH} 7.4)$ with a Potter's homogeniser (Braun, Melsungen, Germany). The homogenates were then subjected to differential centrifugation at $1000 \mathrm{~g}$ for $10 \mathrm{~min}, 15000 \mathrm{~g}$ for $10 \mathrm{~min}$ and $105000 \mathrm{~g}$ for $1 \mathrm{~h}$ at $4^{\circ} \mathrm{C}$ (Mikro-Ultrazentrifuge). The supernatant fractions were used for the measurement of GPx activity. GPx activity in liver was related to the protein concentration ${ }^{(24)}$. The GPX activity from liver is expressed as units of $\mu \mathrm{mol}$ NADPH consumed/min per mg protein. Plasma GPx activity is expressed as units of $\mu \mathrm{mol} \mathrm{NADPH}$ consumed/min per $\mathrm{ml}$.

\section{Analysis of calcium and inorganic phosphate in plasma}

The concentration of $\mathrm{Ca}$ in plasma was measured by inductively coupled plasma optical emission spectrometry (JY 24; Jobin Yvon, Division d'Instruments S.A., Lonjumeau, France) at a wavelength of $393.366 \mathrm{~nm}$. The plasma concentration of inorganic phosphate was measured spectrophotometrically according to the manufacturer's protocol (Fluitest PHOS; Biocon Diagnostik, Vöhl/Marienhagen, Germany).

\section{Analysis of cholesterol oxidation products in $L D L$}

Concentrations of cholesterol oxidation products in the LDL fraction were determined by liquid chromatographyatmospheric pressure chemical ionisation MS according to a recently described method ${ }^{(25)}$ using an API 2000 (Applied Bioscience, Darmstadt, Germany) coupled with an Agilent 1100 HPLC (Agilent, Waldbronn, Germany) after sample preparation by saponification and solid-phase extraction ${ }^{(26)}$. 


\section{Gene expression analysis}

For the determination of hepatic mRNA expression levels of acyl-CoA oxidase (EC 1.3.3.6), apoA5, fatty acid synthase (FAS; $E C$ 2.3.1.85), hepatic lipase (EC 3.1.1.3), 3-hydroxy3-methylglutaryl-CoA synthase (EC 4.1.3.5), LDL receptor, lipoprotein lipase (LPL; EC 3.1.1.34), PPAR- $\alpha$, sterol regulatory element-binding protein-1c and stearoyl-CoA desaturase 1 (EC 1.14.99.5), total RNA was isolated using TRIZOL $^{\text {TM }}$ reagent (Invitrogen, Karlsruhe, Germany) according to the manufacturer's instructions. RNA concentration and purity were estimated from the optical density at 260 and $280 \mathrm{~nm}$, respectively. Total RNA $(1.2 \mu \mathrm{g})$ was subjected to firststrand cDNA synthesis at $42^{\circ} \mathrm{C}$ for $60 \mathrm{~min}$ using M-MuLV RT (MBI Fermentas, St Leon-Rot, Germany) and oligo dT18-primer (Operon Biotechnologies, Cologne, Germany). The mRNA concentrations of genes were measured by realtime PCR using the RotorGene 2000 system (Corbett Research, Mortlake, NSW, Australia). Real-time detection was performed by using SYBR $^{\circledR}$ Green I (Sigma), $1.25 \mathrm{U}$ Taq DNA polymerase (Promega, Mannheim, Germany), $500 \mu \mathrm{M}-\mathrm{dNTPs}$ and $26.7 \mathrm{pmol}$ of the specific primers (Operon Biotechnologies; Table 3). Each PCR cycle comprised denaturation for $20 \mathrm{~s}$ at $95^{\circ} \mathrm{C}$, annealing for $30 \mathrm{~s}$ at a primer-specific temperature $\left(58-65^{\circ} \mathrm{C}\right)$ and elongation at $72^{\circ} \mathrm{C}$ for $55 \mathrm{~s}$. The intensity of fluorescence in all probes was measured at the end of the elongation step. For determination of mRNA concentration, threshold cycle $\left(C_{\mathrm{t}}\right)$ and amplification efficiency were obtained from each amplification curve using the software RotorGene 4.6 (Corbett Research). Melting-curve analysis and agarose (1\%) gel electrophoresis were performed for identification of the PCR products. The housekeeping gene $\beta$-actin was used for normalisation.

\section{Statistics}

Data were treated by one-way ANOVA using MINITAB software (Minitab, State College, PA, USA). For statistically significant $F$ values $(P<0 \cdot 05)$, means of the three groups were compared by Fisher's multiple-range test. Means were considered significantly different at $P<0 \cdot 05$.

All experimental procedures described followed established guidelines for the care and handling of laboratory animals ${ }^{(27)}$ and were approved by the Committee on Animal Care (Halle, Saxony-Anhalt, Germany; approval number 42505-3-508).

\section{Results}

Food intake, body weight and liver weight

The daily food intake, the final body weights and also liver weights were similar in all groups of mice (Table 4).

\section{Lipid concentrations in plasma lipoproteins and liver}

Mice fed the lupin protein diet and the cysteine-supplemented casein diet had higher concentrations of TAG in VLDL than mice fed the control diet with casein $(P<0.05$; Table 4$)$. The concentrations of TAG in the liver were not significantly influenced by the dietary treatments. The cholesterol concentrations in VLDL, HDL and liver were not different between the three groups of mice (Table 4). Mice fed the cysteinesupplemented casein diet had lower LDL-cholesterol levels than mice fed the lupin protein diet $(P<0.05)$. No difference in LDL-cholesterol was observed between the group fed the lupin protein diet and the group fed the casein diet.

\section{Aortic atherosclerosis}

Analysis of the aortic root sections showed that all mice had severe atherosclerosis. All plaques had an intact surface without rupture or luminal thrombosis. Compared with the control mice fed casein, significantly less calcified area was observed in the mice fed the lupin protein diet and the cysteinesupplemented casein diet $(P<0 \cdot 05$; Figs. 1(A) and 2(A)). Mean atherosclerotic lesion size (Fig. 1(B)), levels of collagen

Table 3. Primer sequences for real-time PCR of genes involved in lipid metabolism of apoE-deficient mice fed the experimental diets

\begin{tabular}{|c|c|c|c|}
\hline Gene & GenBank no. & Primer sequence & \\
\hline \multirow[t]{2}{*}{$\mathrm{ACO}$} & \multirow[t]{2}{*}{ NM_015729.2 } & Forward: & $5^{\prime} \mathrm{CAG}$ GAA GAG CAA GGA AGT GG $3^{\prime}$ \\
\hline & & Reverse: & $5^{\prime}$ CCT TTC TGG CTG ATC CCA TA $3^{\prime}$ \\
\hline \multirow[t]{2}{*}{ ApoA5 } & \multirow[t]{2}{*}{ NM_080434.3 } & Forward: & $5^{\prime}$ CCT GCA GAT TGC TGC ATT TA $3^{\prime}$ \\
\hline & & Reverse: & 5'GTT AAC CGG AGT GAC CCT CA $3^{\prime}$ \\
\hline \multirow[t]{2}{*}{$\beta$-Actin } & \multirow[t]{2}{*}{ NM_007393.2 } & Forward: & $5^{\prime}$ ACG GCC AGG TCA TCA CTA TTG $3^{\prime}$ \\
\hline & & Reverse: & $5^{\prime} \mathrm{CAC}$ AGG ATT CCA TAC CCA AGA AG $3^{\prime}$ \\
\hline \multirow[t]{2}{*}{ FAS } & \multirow[t]{2}{*}{ NM_007988.3 } & Forward: & 5'TGG GTT CTA GCC AGC AGA GT 3' \\
\hline & & Reverse: & $5^{\prime} \mathrm{ACC}$ ACC AGA GAC CGT TAT GC $3^{\prime}$ \\
\hline \multirow[t]{2}{*}{ Hepatic lipase } & \multirow[t]{2}{*}{ NM_008280.2 } & Forward: & $5^{\prime}$ GAC TGG ATC TCC CTG GCA TA $3^{\prime}$ \\
\hline & & Reverse: & $5^{\prime} \mathrm{AGG}$ TGA ACT TTG CTC CGA GA $3^{\prime}$ \\
\hline \multirow[t]{2}{*}{ LDL receptor } & \multirow[t]{2}{*}{ NM_010700.2 } & Forward: & 5'CAG CTC TGT GTG AAC CTG GA $3^{\prime}$ \\
\hline & & Reverse: & $5^{\prime}$ TCA GGG CGC TGT AGA TCT TT $3^{\prime}$ \\
\hline \multirow[t]{2}{*}{ LPL } & \multirow[t]{2}{*}{ NM_008509.2 } & Forward: & 5'GGG CTC TGC CTG AGT TGT AG $3^{\prime}$ \\
\hline & & Reverse: & 5'AGA AAT TTC GAA GGC CTG GT $3^{\prime}$ \\
\hline \multirow[t]{2}{*}{$\operatorname{PPAR} \alpha$} & \multirow[t]{2}{*}{ NM_011144.3 } & Forward: & $5^{\prime} \mathrm{CGG}$ GAA AGA CCA GCA ACA AC $3^{\prime}$ \\
\hline & & Reverse: & 5'TGG CAG CAG TGG AAG AAT CG $3^{\prime}$ \\
\hline \multirow[t]{2}{*}{ SCD1 } & \multirow[t]{2}{*}{ NM_009127.3 } & Forward: & $5^{\prime} \mathrm{AGG}$ TGC CTC TTA GCC ACT GA $3^{\prime}$ \\
\hline & & Reverse: & $5^{\prime}$ CTG CTG AGG ATC CCC AAA TA $3^{\prime}$ \\
\hline \multirow[t]{2}{*}{ SREBP-1c } & \multirow[t]{2}{*}{ NM_011480.2 } & Forward: & 5'ATC GGC GCG GAA GCT GTC GGG GTA GCG TC $3^{\prime}$ \\
\hline & & Reverse: & 5'ACT GTC TTG GTT GTT GAT GAG CTG GAG CAT $3^{\prime}$ \\
\hline
\end{tabular}

ACO, acyl-CoA oxidase; FAS, fatty acid synthase; LPL, lipoprotein lipase; SCD, stearoyl-CoA desaturase; SREBP, sterol regulatory element-binding protein 
Table 4. Food intake, body and liver weights and concentrations of cholesterol and TAG in lipoproteins and liver of apoE-deficient mice fed the experimental diets

(Mean values and standard deviations for ten mice per group)

\begin{tabular}{|c|c|c|c|c|c|c|}
\hline & \multicolumn{2}{|c|}{$\begin{array}{l}\text { Control diet with } \\
\text { casein }\end{array}$} & \multicolumn{2}{|c|}{ Lupin protein diet } & \multicolumn{2}{|c|}{$\begin{array}{l}\text { Cysteine- } \\
\text { supplemented casein die }\end{array}$} \\
\hline & Mean & SD & Mean & SD & Mean & SD \\
\hline Daily food intake (g) & 2.93 & 0.37 & $2 \cdot 86$ & 0.23 & 3.04 & 0.38 \\
\hline Final body weight $(\mathrm{g})$ & $31 \cdot 3$ & $2 \cdot 1$ & 32.5 & $2 \cdot 4$ & $32 \cdot 0$ & $2 \cdot 7$ \\
\hline $\begin{array}{l}\text { Liver weight }(\mathrm{g}) \\
\text { TAG }\end{array}$ & 1.43 & $0 \cdot 17$ & 1.48 & $0 \cdot 18$ & $1 \cdot 31$ & $0 \cdot 26$ \\
\hline VLDL (mmol/l) & $0.21^{b}$ & 0.04 & $0.31^{a}$ & 0.07 & $0.30^{a}$ & 0.03 \\
\hline Liver $(\mu \mathrm{mol} / \mathrm{g})$ & 45.9 & 29.5 & $79 \cdot 3$ & $31 \cdot 3$ & $65 \cdot 6$ & $37 \cdot 8$ \\
\hline \multicolumn{7}{|l|}{ Cholesterol } \\
\hline VLDL (mmol) & 9.9 & $3 \cdot 1$ & $15 \cdot 5$ & 3.4 & $12 \cdot 2$ & 3.5 \\
\hline $\mathrm{LDL}(\mathrm{mmol} / \mathrm{l})$ & $11 \cdot 0^{\mathrm{a}, \mathrm{b}}$ & $2 \cdot 2$ & $12 \cdot 4^{\mathrm{a}}$ & 0.9 & $8.9^{\mathrm{b}}$ & $1 \cdot 8$ \\
\hline $\mathrm{HDL}(\mathrm{mmol} / \mathrm{l})$ & 7.53 & 3.48 & $5 \cdot 75$ & 0.58 & 4.80 & 1.75 \\
\hline Liver $(\mu \mathrm{mol} / \mathrm{g})$ & $23 \cdot 3$ & 8.6 & 29.9 & 6.8 & $24 \cdot 7$ & $7 \cdot 3$ \\
\hline
\end{tabular}

${ }^{\mathrm{a}, \mathrm{b}}$ Mean values within a row with unlike superscript letters were significantly different $(P<0.05$; one-way ANOVA and Fisher's multiple-range test).

(Figs. 1(C) and 2(B)) and lipids (Figs. 1(D) and 2(C)) did not differ between the three groups of mice.

Cysteine, homocysteine, glutathione concentrations and glutathione peroxidase activity in plasma and liver, and plasma concentrations of calcium and inorganic phosphate

The concentration of cysteine in plasma did not differ between the three groups of mice (Table 5). Mice fed the casein diet supplemented with cysteine had higher cysteine concentrations in their livers than mice fed the control diet with casein or the lupin protein diet $(P<0 \cdot 05)$. The concentration of homocysteine in plasma and liver was not different between the three groups of mice. The concentration of total glutathione in plasma was lower in mice fed the lupin protein diet and the cysteine-supplemented casein diet than in mice fed the control diet with casein $(P<0.05)$; however, the hepatic glutathione concentration was not influenced by the diets (Table 5). The activity of GPx in plasma and liver and the plasma concentrations of $\mathrm{Ca}$ and inorganic
(A)

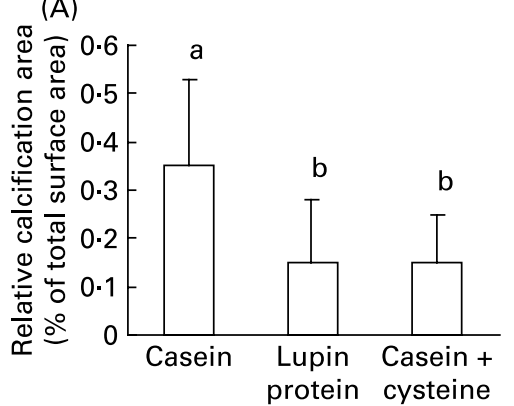

(C)

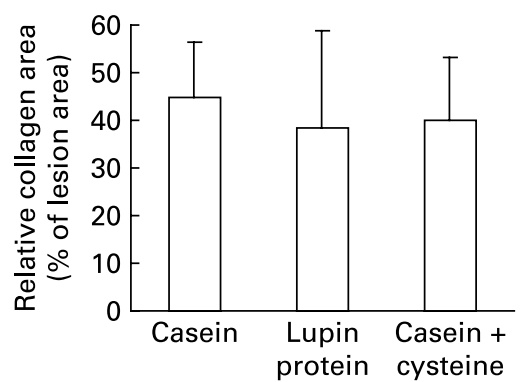

(B)

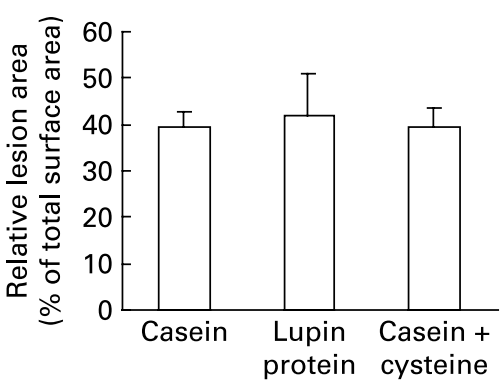

(D)

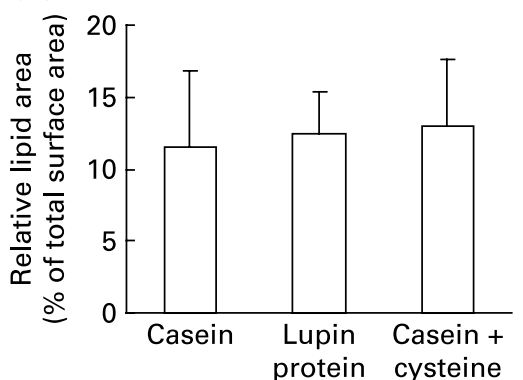

Fig. 1. Analysis of the aortic root sections of apoE-deficient mice fed the experimental diets with either casein, lupin protein or cysteine-supplemented casein for 4 months. (A) Calcified area relative to total surface area; (B) lesion size relative to total surface area; (C) collagen area relative to the lesion area; (D) lipid area relative to total surface area. To quantify atherosclerosis, $10 \mu \mathrm{m}$ thick sections from the aortic root were stained with haematoxylin-eosin for overview, von Kossa for vascular calcification, Goldner's trichrome for collagen structures and Oil red $O$ for vascular lipids. Results are means ( $n$ 10), with standard deviations represented by vertical bars. ${ }^{a, b}$ Mean values with unlike letters were significantly different $(P<0 \cdot 05$; Fisher's multiple-range test). 
(A)

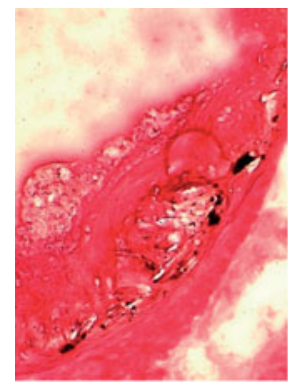

(B)

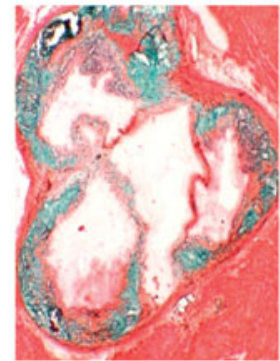

(C)

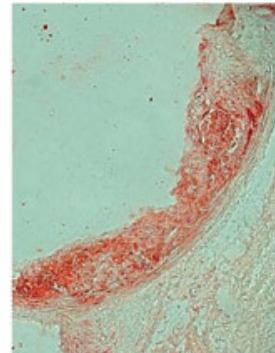

Control diet with casein
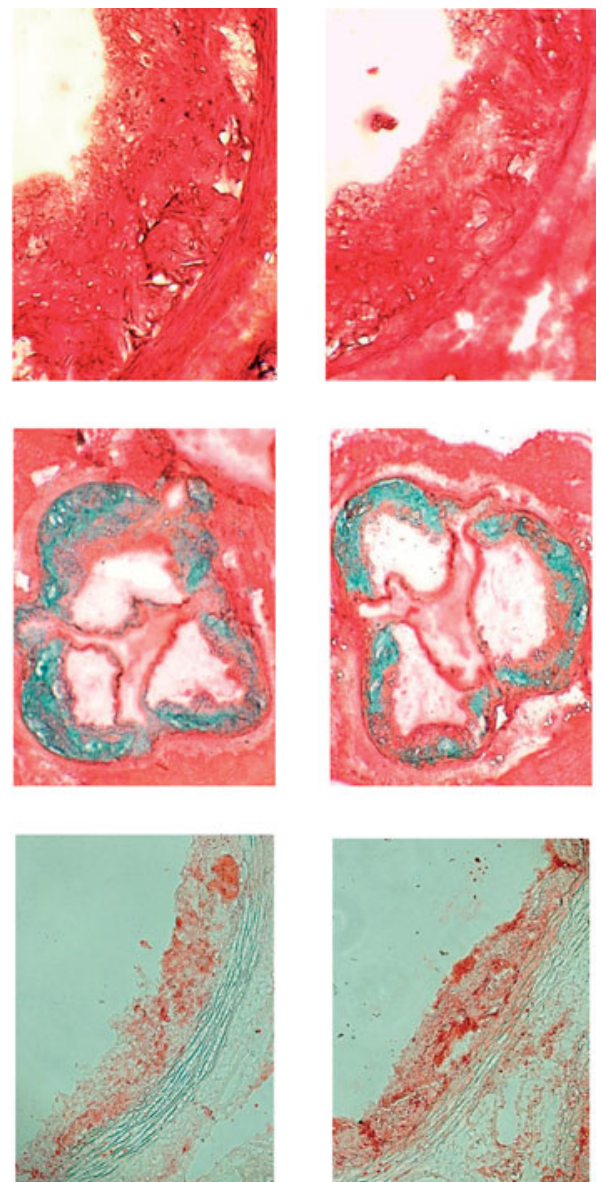

Lupin protein diet

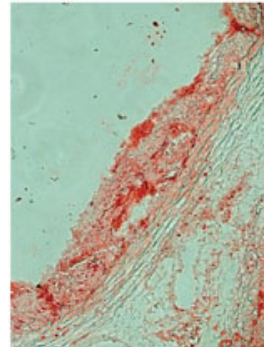

Cysteine-supplemented casein diet

Fig. 2. Stained aortic root sections of representative apoE-deficient mice fed the experimental diets with either casein, lupin protein or cysteine-supplemented casein for 4 months. (A) von Kossa staining of calcification; (B) Goldner's trichrome staining of collagen structures; (C) Oil red $\mathrm{O}$ staining of lipids.

phosphate were not different between the three groups of mice (Table 5).

Concentrations of cholesterol oxidation products in the $L D L$ fraction

The concentration of $7 \beta$-hydroxycholesterol in the LDL fraction tended to be higher in mice fed cysteine-supplemented casein than in mice fed lupin protein or casein $(P=0.056)$. The mice fed cysteine-supplemented casein had a higher concentration of 7-keto-cholesterol in the LDL fraction than the mice fed lupin protein or casein alone $(P<0.05)$.

\section{Hepatic mRNA concentrations of genes involved in lipid metabolism}

The hepatic mRNA concentrations of PPAR $\alpha$, acyl-CoA oxidase, apoA5, hepatic lipase and LPL (involved in TAG catabolism), the hepatic mRNA levels of sterol regulatory element-binding protein-1c, FAS and stearoyl-CoA desaturase 1 (involved in TAG synthesis) as well as the mRNA levels of the LDL receptor were not different between the group fed the lupin protein and the control group fed casein (data not shown). Mice fed the cysteine-supplemented casein diet had a higher hepatic mRNA concentration of LPL than mice fed the casein or lupin protein diet (1.00 (SD 0.49), 1.06 (SD 0.45) and 2.09 (SD 1.19) for the casein, lupin protein and cysteine-supplemented casein groups, respectively; $P<0.05$ ). They also had a lower mRNA concentration of FAS than mice fed the casein or lupin protein diet (1.00 (SD 0.34), 0.86 (SD 0.60) and 0.44 (SD 0.21) for the casein, lupin protein and cysteine-supplemented casein groups, respectively; $P<0.05$ ).

\section{Discussion}

In the present study we addressed the question whether lupin protein and cysteine-enriched casein can affect atherosclerosis development compared with casein. All animals developed atherosclerosis within 4 months, which was quite apparent by the significant lesions in the whole aorta. As a main finding we could demonstrate for the first time a significant reduction of calcified areas in the aortic plaque lesions by more than $50 \%$ in mice fed protein from blue lupin and cysteinesupplemented casein compared with mice fed casein alone. However, lesion sizes, lesion collagen and lipid contents were not influenced by the type of dietary protein. 
Table 5. Concentrations of cysteine, homocysteine, total glutathione and activity of glutathione peroxidase in plasma and liver, plasma concentrations of calcium and inorganic phosphate and concentrations of cholesterol oxidation products in LDL of apoE-deficient mice fed the experimental diets (Mean values and standard deviations for ten mice per group)

\begin{tabular}{|c|c|c|c|c|c|c|}
\hline & \multicolumn{2}{|c|}{ Control diet with casein } & \multicolumn{2}{|c|}{ Lupin protein diet } & \multicolumn{2}{|c|}{$\begin{array}{l}\text { Cysteine-supplemented } \\
\text { casein diet }\end{array}$} \\
\hline & Mean & SD & Mean & SD & Mean & SD \\
\hline \multicolumn{7}{|l|}{ Plasma } \\
\hline Cysteine $(\mu \mathrm{mol} / \mathrm{l})$ & 125 & 34 & 127 & 31 & 115 & 33 \\
\hline Homocysteine $(\mu \mathrm{mol} / \mathrm{l})$ & $5 \cdot 7$ & $2 \cdot 0$ & $5 \cdot 2$ & 1.4 & 4.6 & $2 \cdot 8$ \\
\hline Glutathione $(\mu \mathrm{mol} / \mathrm{l})$ & $28 \cdot 9^{a}$ & 8.9 & $21 \cdot 8^{\mathrm{b}}$ & 3.8 & $18 \cdot 4^{\mathrm{b}}$ & 5.0 \\
\hline Glutathione peroxidase $(\mathrm{U} / \mathrm{ml})^{\star}$ & 1.39 & 0.26 & $1 \cdot 18$ & 0.19 & 1.40 & 0.42 \\
\hline $\mathrm{Ca}(\mathrm{mmol} / \mathrm{l})$ & 2.45 & $0 \cdot 16$ & 2.34 & 0.05 & 2.42 & 0.10 \\
\hline Inorganic phosphate $(\mathrm{mmol} / \mathrm{l})$ & 7.04 & 3.60 & 8.73 & 1.97 & 7.63 & $2 \cdot 12$ \\
\hline \multicolumn{7}{|l|}{ LDL } \\
\hline $7 \beta$-Hydroxycholesterol $(\mu \mathrm{mol} / \mathrm{l})$ & $2 \cdot 32$ & 0.80 & $2 \cdot 21$ & $0 \cdot 10$ & 3.00 & 0.36 \\
\hline 7-Keto-cholesterol $(\mu \mathrm{mol} / \mathrm{l})$ & $0.46^{\mathrm{b}}$ & $0 \cdot 10$ & $0.50^{\mathrm{b}}$ & 0.04 & $0.72^{\mathrm{a}}$ & 0.09 \\
\hline \multicolumn{7}{|l|}{ Liver } \\
\hline Cysteine $(\mathrm{mmol} / \mathrm{g})$ & $0.51^{\mathrm{b}}$ & 0.12 & $0.53^{\mathrm{b}}$ & 0.13 & $0.73^{\mathrm{a}}$ & 0.19 \\
\hline Homocysteine $(\mu \mathrm{mol} / \mathrm{g})$ & $65 \cdot 0$ & 10.5 & 63.5 & 13.2 & $71 \cdot 1$ & $5 \cdot 8$ \\
\hline Glutathione $(\mathrm{mmol} / \mathrm{g})$ & $9 \cdot 7$ & $1 \cdot 3$ & $8 \cdot 8$ & 1.4 & 8.8 & 1.3 \\
\hline Glutathione peroxidase (U/mg protein) ${ }^{*}$ & $1 \cdot 17$ & 0.07 & $1 \cdot 21$ & 0.24 & $1 \cdot 21$ & 0.22 \\
\hline
\end{tabular}

a,b Mean values within a row with unlike superscript letters were significantly different $(P<0.05$; one-way ANOVA and Fisher's multiple-range test).

${ }^{*} 1 \mathrm{U}$ is defined as $1 \mu \mathrm{mol}$ NADPH consumed/min.

It is well known that atherosclerotic lesions progress from fatty streaks through stages that include atheroma with large necrotic areas, fibro-fatty nodules containing chondrocyte-like cells and highly calcified, acellular plaques. Until recently, vascular calcification was considered to be a passive, degenerative, end-stage process of vascular disease. Merging evidence, however, suggests that calcification occurs much earlier in atherosclerosis than previously believed and that it involves complex regulated mechanisms ${ }^{(28)}$. Vascular calcification reduces elasticity, increases resting vascular smooth muscle tone and vascular stiffness, raises blood pressure, and is associated with cardiovascular morbidity and mortality ${ }^{(29,30)}$. On the other hand, it has been suggested that a highly calcified fibrous cap may create a barrier that protects plaques from rupture ${ }^{(31)}$. Interestingly, investigations into the size and distribution of calcified deposits in atherosclerotic plaques have suggested that diffuse, 'speckled', or 'spotty' deposits cause local plaque stress and plaque instability, whereas large plate-like areas of calcification correlate with stable plaques ${ }^{(32-34)}$. It has been further found that speckled calcified deposits are commonly found in ruptured coronary plaques ${ }^{(32)}$. In the present study all mice seemed to have speckled calcified deposits but mice fed the lupin protein and the cysteine-supplemented casein had a smaller number of calcified spots than the mice fed casein. Thus, we can speculate that mice fed with lupin protein and cysteine could have less plaque stress and more plaque stability than mice fed the casein diet.

Vascular calcification has been shown to be regulated by promoting factors, such as inorganic phosphate ${ }^{(35)}$, oxidative modified LDL $^{(35)}$, oxidative stress ${ }^{(36)}$, mild hyperhomocysteinaemia $^{(37)}$, hypercholesterolaemia ${ }^{(38)}$ and hypertriacylglycerolaemia ${ }^{(39)}$. In the present study the lipid concentrations in plasma and lipoproteins cannot account for the observed effects on aortic calcification because the cholesterol in lipoproteins was not affected by the dietary treatments and the TAG in VLDL was even higher in mice fed lupin protein and cysteine-supplemented casein than in the control mice fed casein. The failure of lupin protein and cysteine to have a lipid-lowering effect is in contrast to other studies in which lupin protein $^{(3,4)}$ and cysteine-containing compounds $^{(15,16)}$ exerted cholesterol- and TAG-lowering properties. We speculate that the use of the apoE-deficient mouse model could be the reason for the failure of the lupin protein and cysteine to reduce circulating lipids because isolated soya protein, a potential lipid-lowering protein, exerts also no effects on plasma lipids in apoE-deficient mice ${ }^{(11,40)}$. Despite the lack of effect on plasma lipids in these studies, isolated soya protein fed to apoE-deficient mice was capable of reducing atherosclerotic processes ${ }^{(11,40)}$, and recent data further confirm that aortic calcification seems to be partly independent of serum cholesterol levels ${ }^{(41)}$.

VLDL TAG, which are increased in the mice fed lupin protein or cysteine-supplemented casein, are formed in the liver and their amounts in plasma depend on the balance between formation in the liver and degradation. The observed effects on VLDL TAG could not be explained on the basis of alterations in gene expression because the relative mRNA concentrations of genes involved in TAG catabolism such as LPL, hepatic lipase, apoA5, PPAR $\alpha$ and acyl-CoA oxidase or genes involved in TAG synthesis such as sterol regulatory element-binding protein-1c, FAS and stearoyl-CoA desaturase 1 were not altered in these animals compared with the controls. Further studies should be performed by using other atherosclerosis models such as LDL receptor-deficient mice to elucidate whether the observed TAG-raising effect is only observed in the apoE-deficient mouse model.

In addition to the classical Framingham risk factors, disturbed $\mathrm{Ca}$ and $\mathrm{P}$ metabolism may contribute to the development of vascular calcification. An increasing number of studies are providing direct evidence for the role of inorganic phosphate concentration in plasma in the development of vascular calcification ${ }^{(42,43)}$. Data obtained from the present study did not show any differences in the plasma concentrations of $\mathrm{Ca}$ and inorganic phosphate between the three groups of 
mice. Thus, the circulating minerals could not explain the differences in vascular calcification. The lupin protein diet differs from the casein diet in the proportion of methionine $(3.6$ v. $5.8 \mathrm{~g} / \mathrm{kg}$ diet) and cysteine $(3.7 v .2 .8 \mathrm{~g} / \mathrm{kg} \mathrm{diet})$. In light of the recently clarified role of these amino acids in atherogenesis, it was expected that the high proportions of methionine in casein would result in more homocysteine, which would lead to the development of calcification ${ }^{(44)}$. In the present study, plasma concentrations of homocysteine were not different between the treatment groups.

Oxidative stress may accelerate vascular calcification ${ }^{(36)}$, and we assume that the antioxidative potential of cysteine could have contributed to an improved antioxidant status. Cysteine is a precursor of glutathione, one of the most important antioxidants in mammalian cells, and a high concentration of glutathione makes the molecule an effective redox buffer to adsorb excessive free radicals ${ }^{(45)}$. The liver is the principal contributor to the de novo glutathione synthesis and controls the distribution of glutathione toward the peripheral organs ${ }^{(46)}$. It was further found that cysteine availability is often limiting for synthesis of glutathione ${ }^{(47)}$. However, glutathione concentrations in the liver and GPx activities in the liver and plasma were not different between the groups of mice, and plasma concentration of glutathione was even lower in mice fed the cysteine-supplemented casein than in mice fed casein alone.

Other factors which are known to stimulate vascular calcification are oxidised derivatives of cholesterol, known as oxysterols ${ }^{(48,49)}$. Indeed, 7 $\beta$-hydroxycholesterol and 7-ketocholesterol, which are major components of oxidised LDL, are known to contribute to the genesis of atherosclerosis and vascular calcification ${ }^{(48-50)}$. Although all groups of mice had relatively low concentrations of oxysterols, mice fed cysteine-supplemented casein had higher concentrations of both oxysterols in the LDL fraction than mice fed lupin protein or casein without additional cysteine. Thus, oxysterols in LDL also do not provide an explanation for the effects of lupin protein and cysteine on calcification.

In summary, the present study confirmed that lupin protein and cysteine-enriched casein appear to cause a shift in plaque morphology without affecting plaque size in the apoEdeficient mouse model. Although the mechanisms by which lupin protein and cysteine reduce the calcification process in the aortic root remain unclear, we conclude that the consumption of lupin protein and cysteine-rich proteins decelerate a very problematic stage of atherogenesis, even though the findings are restricted to the apoE-deficient mouse model since apoE deficiency is not common in humans. We also conclude that this effect was not mediated by effects on plasma lipoproteins, homocysteine, $\mathrm{Ca}$, inorganic phosphate, or oxidative or antioxidative parameters.

\section{Acknowledgements}

The research was supported by a grant from the Bundesministerium für Wirtschaft und Technologie (BMWi).

The authors thank Dr Daniel Teupser, Dr Frank Beutner and Doris Ludwig from the Institute of Laboratory Medicine, Clinical Chemistry and Molecular Diagnostics, University Hospital Leipzig, for their very helpful advice and manysided suggestions in terms of sample collection and tissue preparation as well as histological staining and analysis. We also thank Dr Rene Schmidt and Mrs Elke Gebauer for their very kind technical assistance dealing with the microtome, staining procedures and analysing software and $\mathrm{Mr}$ Nico Markus for the analysis of the $\mathrm{Ca}$ concentration (all from the of Institute of Agricultural and Nutritional Sciences, Martin Luther University Halle-Wittenberg).

$\mathrm{K}$. W. carried out the animal experiment, determined the mRNA concentrations of the hepatic genes, performed HPLC analyses, participated in the interpretation of the results and helped to draft the manuscript. C. B. planned the animal experiment and participated in the sample analysis. F. $\mathrm{H}$. supervised all HPLC and MS analysis. K. E. participated in the design of the study and interpretation of the results. G. I. S. conceived of the study and its design, coordinated work, participated in the interpretation of the results and prepared the manuscript.

There are no potential conflicts of interest.

\section{References}

1. Petterson DS (1998) Composition and food uses of lupins. Lupins as Crop Plants: Biology, Production, and Utilization, pp. 353-384 [JS Gladstones, CA Atkins and J Hamblin, editors]. Wallingford, UK: CAB International.

2. Xiao CW, Mei J \& Wood CM (2008) Effect of soy proteins and isoflavones on lipid metabolism and involved gene expression. Front Biosci 13, 2660-2673.

3. Sirtori CR, Lovati MR, Manzoni C, et al. (2004) Proteins of white lupin seed, a naturally isoflavone-poor legume, reduce cholesterolemia in rats and increase LDL receptor activity in HepG2 cells. $J$ Nutr 134, 18-23.

4. Marchesi M, Parolini C, Diani E, et al. (2008) Hypolipidaemic and anti-atherosclerotic effects of lupin proteins in a rabbit model. Br J Nutr 100, 707-710.

5. Bettzieche A, Brandsch C, Weisse K, et al. (2008) Lupin protein influences the expression of hepatic gene involved in fatty acid synthesis and triacylglycerol hydrolysis of adult rats. $\mathrm{Br} \mathrm{J}$ Nutr 99, 952-962.

6. Spielmann J, Shukla A, Brandsch C, et al. (2007) Dietary lupin protein lowers triglyceride concentrations in liver and plasma in rats by reducing hepatic gene expression of sterol regulatory element-binding protein-1c. Ann Nutr Metab 51, 387-392.

7. Nakashima Y, Plump AS, Raines EW, et al. (1994) ApoEdeficient mice develop lesions of all phases of atherosclerosis throughout the arterial tree. Arterioscler Thromb 14, 133-140.

8. Zhang SH, Reddick RL, Piedrahita JA, et al. (1992) Spontaneous hypercholesterolemia and arterial lesions in mice lacking apolipoprotein E. Science 258, 468-471.

9. Shukla A, Brandsch C, Bettzieche A, et al. (2007) Isoflavonepoor soy protein alters the lipid metabolism of rats by SREBP-mediated down-regulation of hepatic genes. $J$ Nutr Biochem 18, 313-321.

10. Yang L, Kumagai T, Kawamura H, et al. (2007) Effects of rice proteins from two cultivars, Koshihikari and Shunyo, on cholesterol and triglyceride metabolism in growing and adult rats. Biosci Biotechnol Biochem 71, 694-703.

11. Nagarajan S, Burris RL, Stewart BW, et al. (2008) Dietary soy protein isolate ameliorates atherosclerotic lesions in apolipoprotein E-deficient mice potentially by inhibiting monocyte chemoattractant protein-1 expression. J Nutr 138, 332-337.

12. Sanchez A \& Hubbard RW (1991) Plasma amino acids and the insulin/glucagon ratio as an explanation for the dietary protein modulation of atherosclerosis. Med Hypotheses 36, 27-32. 
13. Potter SM (1995) Overview of proposed mechanisms for the hypocholesterolemic effect of soy. J Nutr 125, 606S-611S.

14. Shukla A, Bettzieche A, Hirche F, et al. (2006) Dietary fish protein alters blood lipid concentrations and hepatic genes involved in cholesterol homeostasis in the rat model. Br J Nutr 96, 674-682.

15. Lin CC, Yin MC, Hsu CC, et al. (2004) Effect of five cysteinecontaining compounds on three lipogenic enzymes in Balb/cA mice consuming a high saturated fat diet. Lipids 39, 843-848.

16. Lin CC \& Yin MC (2008) Effects of cysteine-containing compounds on biosynthesis of triacylglycerol and cholesterol and anti-oxidative protection in liver from mice consuming a highfat diet. Br J Nutr 99, 37-43.

17. Reeves PG, Nielsen FH \& Fahey GC Jr (1993) AIN-93 purified diets for laboratory rodents: final report of the American Institute of Nutrition ad hoc Writing Committee on the Reformulation of the AIN-76A Rodent Diet. J Nutr 123, 1939-1951.

18. Wäsche A, Müller K \& Knauf U (2001) New processing of lupin protein isolates and functional properties. Nahrung $\mathbf{4 5}$, 393-395.

19. Sung JH, Choi SJ, Lee SW, et al. (2004) Isoflavones found in Korean soybean paste as 3-hydroxy-3-methylglutaryl coenzyme A reductase inhibitors. Biosci Biotechnol Biochem 68 , 1051-1058.

20. Teupser D, Persky AD \& Breslow JL (2003) Induction of atherosclerosis by low-fat, semisynthetic diets in LDL receptordeficient C57BL/6J and FVB/NJ mice: comparison of lesions of the aortic root, brachiocephalic artery, and whole aorta (en face measurement). Arterioscler Thromb Vasc Biol 23, 1907-1913.

21. Mueller MA, Beutner F, Teupser D, et al. (2008) Prevention of atherosclerosis by the mTOR inhibitor everolimus in $\mathrm{LDLR}^{-1-}$ mice despite severe hypercholesterolemia. Atherosclerosis 198, $39-48$.

22. Vester B \& Rasmussen K (1991) High performance liquid chromatography method for rapid and accurate determination of homocysteine in plasma and serum. Eur J Clin Chem Clin Biochem 29, 549-554.

23. Levander OA, Deloach DP, Morris VC, et al. (1983) Platelet glutathione peroxidase activity as an index of selenium status in rats. $J$ Nutr 113, 55-63.

24. Bradford MM (1976) A rapid and sensitive method for the quantitation of microgram quantities of protein utilizing the principle of protein-dye binding. Anal Biochem 72, 248-254.

25. Raith K, Brunner C, Farwanah H, et al. (2005) A new LC/APCI-MS method for the determination of cholesterol oxidation products in food. $J$ Chromatogr A 1067, 207-211.

26. Burkhard I, Rentsch KM \& von Eckardstein A (2004) Determination of 24S- and 27-hydroxycholesterol in plasma by high-performance liquid chromatography-mass spectrometry. J Lipid Res 45, 776-781.

27. National Research Council (1985) Guide for the Care and Use of Laboratory Animals. Publication no. 85-23 (rev.). Washington, DC: National Institutes of Health.

28. Ketteler M \& Giachelli C (2006) Novel insights into vascular calcification. Kidney Int Suppl. 105, S5-S9.

29. Greenwald SE (2007) Ageing of the conduit arteries. J Pathol 211, 157-172.

30. Abedin M, Tintut Y \& Demer LL (2004) Vascular calcification: mechanisms and clinical ramifications. Arterioscler Thromb Vasc Biol 24, 1161-1170.
31. Doherty TM \& Detrano RC (1994) Coronary arterial calcification as an active process: a new perspective on an old problem. Calcif Tissue Int 54, 224-230.

32. Virmani R, Burke AP, Kolodgie FD, et al. (2003) Pathology of the thin-cap fibroatheroma: a type of vulnerable plaque. J Interv Cardiol 16, 267-272.

33. Ehara S, Kobayashi Y, Yoshiyama M, et al. (2004) Spotty calcification typifies the culprit plaque in patients with acute myocardial infarction: an intravascular ultrasound study. Circulation 110, 3424-3429.

34. Vengrenyuk Y, Carlier S, Xanthos S, et al. (2006) A hypothesis for vulnerable plaque rupture due to stress-induced debonding around cellular microcalcifications in thin fibrous caps. Proc Natl Acad Sci U S A 103, 14678-14683.

35. Towler DA, Shao JS, Cheng SL, et al. (2006) Osteogenic regulation of vascular calcification. Ann N Y Acad Sci 1068, 327-333.

36. Byon CH, Javed A, Dai Q, et al. (2008) Oxidative stress induces vascular calcification through modulation of the osteogenic transcription factor runx-2 by akt signaling. J Biol Chem 283, 15319-15327.

37. Hirose N, Arai Y, Ishii T, et al. (2001) Association of mild hyperhomocysteinemia with aortic calcification in hypercholesterolemic patients. J Atheroscler Thromb 8, 91-94.

38. Tang FT, Chen SR, Wu XQ, et al. (2006) Hypercholesterolemia accelerates vascular calcification induced by excessive vitamin D via oxidative stress. Calcif Tissue Int 79, 326-339.

39. Tankó LB, Bagger YZ, Qin G, et al. (2005) Enlarged waist combined with elevated triglycerides is a strong predictor of accelerated atherogenesis and related cardiovascular mortality in postmenopausal women. Circulation 111, 1883-1890.

40. Ni W, Tsuda Y, Sakono M, et al. (1998) Dietary soy protein isolate, compared with casein, reduces atherosclerotic lesion area in apolipoprotein E-deficient mice. J Nutr 128, 1884-1889.

41. Alrasadi K, Alwaili K, Awan Z, et al. (2009) Aortic calcifications in familial hypercholesterolemia: potential role of the low-density lipoprotein receptor gene. Am Heart J 157, 170-176.

42. Caudarella R, Vescini F, Buffa A, et al. (2007) Hyperphosphatemia: effects on bone metabolism and cardiovascular risk. J Endocrinol Invest 30, 29-34.

43. Shioi A \& Nishizawa Y (2009) Roles of hyperphosphatemia in vascular calcification. Clin Calcium 19, 180-185.

44. Duell PB \& Malinow MR (1997) Homocyst(e)ine: an important risk factor for atherosclerotic vascular disease. Curr Opin Lipidol 8, 28-34.

45. Meister A \& Anderson ME (1983) Glutathione. Annu Rev Biochem 52, 711-760.

46. Ookhtens M \& Kaplowitz N (1998) Role of the liver in interorgan homeostasis of glutathione and cyst(e)ine. Semin Liver Dis 18, 313-329.

47. Mosharov E, Cranford MR \& Banerjee T (2000) The quantitatively important relationship between homocysteine metabolism and glutathione synthesis by the transsulfuration pathway and its regulation by redox changes. Biochemistry 39, 13005-13011.

48. Watson KE, Boström K, Ravindranath R, et al. (1994) TGF- $\beta 1$ and 25-hydroxycholesterol stimulate osteoblast-like vascular cells to calcify. $J$ Clin Invest $\mathbf{9 3}, 2106-2113$.

49. Shao JS, Aly ZA, Lai CF, et al. (2007) Vascular Bmp Msx2 Wnt signalling and oxidative stress in arterial calcification. Ann N Y Acad Sci 1117, 40-50.

50. Brown AJ \& Jessup W (1999) Oxysterols and atherosclerosis. Atherosclerosis 142, 1-28. 